\title{
Effect of Certain Plant Extracts on Mortality, Development and Haemogram of Culex pipiens L. Mosquitoes Larvae
}

\author{
Hossam El-Din M. Zahran and Abir A.Gad ${ }^{1}$
}

\begin{abstract}
The effect of methanolic plant extracts from Solanum nigrum, Acokanthera spectabilis and Heliotropium aegyptiacum were investigated on the larval mortality and development of Culex pipiens L. Also, the effects of the $\mathbf{L C}_{50}$ of the three plant extracts on the larval haemogram were studied. Plant extracts exhibited variable bioactivities. The greatest activity was observed for $S$. nigrum which showed $\mathrm{LC}_{50}$ values of $130.8 \mathrm{ppm}$ after $48 \mathrm{hr}$ of exposure, respectively. Percentage of larval mortality was $67.5 \%$ in the treatment with extracts of $S$. nigrum and $66.5 \%$ in case of $A$. spectabilis at 500ppm. Egg hatchability was not significantly reduced in all $S$. nigrum concentrations. All concentrations of the plant extracts from $S$. nigrum, A. spectabilis and $H$. aegyptiacum caused significant hindrance to the subsequent larval development and reduced both pupation and adult emergence. Drastic retardation of development was shown by $S$. nigrum extracts, where only $18.1 \%$ and $8.5 \%$ of the larval managed to reach pupal and adult stages, respectively, when reared in $100 \mathrm{ppm}$ of the extract. However, $A$. spectabilis and $H$. aegyptiacum were more effective at higher concentrations. Moreover, the effects of the $\mathrm{LC}_{50}$ of tested plant extracts caused a reduction in the number of haemocytes and also markedly decreased the haemocytes surface areas. Application of such plant extracts to mosquito breeding site may have great practical importance in relation to non-synthetic chemical control of this serious disease vectors.
\end{abstract}

\section{INTRODUCTION}

The house mosquito, Culex pipiens L. (Diptera: Culicidae) is one of the most harmful insects affecting humans and farm animals and transferring several pathogens as Cache-Valley (CV) and West Nile Virus that cause infertility and congenital malformations in ruminants (Edwards et al., 1998 and Smartt and Erickson, 2008). This insect showed great resistance to the used synthetic insecticides by many mechanisms (Raymond et al., 2001, Dary et al., 1990). It also appeared to be sensitive to several plant extracts and products. Myrrh (oleo-gum-resin) obtained from the stem of Commiphora molmol proved to have insecticidal activity affecting fat, muscles, gut and nervous tissues of the larvae (Massoud and Labib, 2000). Methanolic extracts of aerial parts of the medicinal plant Argel, Solenostemma argel (Del.) Hayne, incorporated into rearing media of Culex pipiens
L. reduced oviposition, hatchability and larval viability (Al-Doghairi et al., 2004). Cetin et al., (2006) reported high larvicidal activity of Teucrium divaricatum Sieber, Mentha longifola (L.) Huds., M. pulegium L., Melissa officinalis L. and Saliva sclarea $\mathrm{L}$. oils against $C$. pipiens. Zhu et al. (2006) reported that the oils of thyme, catnip, amyris, eucalyptus and cinnamon revealed larvicidal activity besides repellent effect on this pest. Several plant species extracts killed and altered developmental periods, pupation rates and adult emergences of this insect (Khater and Shalaby, 2008). Several pure active potential sources of larvicidal substances against mosquito were isolated as betathujaplicin from Chamaecyparis obtuse leaves (Jang et al., 2005), 7-hydroxycoumarin from Stellera chamaejasme root powder (Xiaorong and Taiping, 2008) and pure synthetic natural naphthoquinones (alkannin, shikonin and shikalkin) and three acetylated derivatives of shikonin (Michaelakis et al., 2009). Control of $C$. pipiens is becoming increasingly difficult because the over production of detoxifying mechanisms of chemicals insecticides by this insect (Severini, et al., 1993). The botanical insecticides are generally pest specific and are relatively harmless to non-target organisms including humans. They are also biodegradable and harmless to environment. The phytochemicals derived plant resourses can act as larvicides, insect growth regulators, repellent and ovipositional attractant (Das et al., 2003, Venkatachalam and Jebanesan, 2001). One plant species may possess substances with a wide range of activities, like extracts from Azadiracta indica which showed antifeedent, antioviposition, repellent and growthregulating activity (Schmutterrer, 1995). Insecticidal activity of many plants against several insect pests has been demonstrated (Carlini and Grossi-de-sa, 2002, Kundu, et al., 2007 and Boussada, et al., 2008).

In this study the effects of methanolic extracts of aerial parts from three plant species Solanum nigrum, Acokanthera spectabilis and Heliotropium aegyptiacum on egg hatchability, larval development and different haemocyte counts of $C$. pipiens mosquitoes, have been investigated.

\footnotetext{
${ }^{1}$ Department of Applied Entomology, Faculty of Agriculture, Alexandria University, Egypt

Received May 19, 2013, Accepted June 25, 2013
} 


\section{MATERIALS AND METHODS}

Insects: A Culex pipiens L. (Diptera: Culicidae) colony maintained in the laboratory for more than 10 years was used. Mosquitoes were held at $27 \pm 1 \mathrm{C}^{\circ}, 70 \pm 5 \% \mathrm{RH}$ and a photo period of 14:10 (light:dark). Adults were provided with a $10 \%$ sucrose solution as food source. A pigeon was introduced twice a week to the adults for blood feeding. Larvae were reared in dechlorinated water under the same temperature and light conditions and were fed daily with baby fish food. The experiment was carried out at the faculty of agriculture, Alexandria University, Egypt.

Plant extracts: Fresh fruits (1100 gm) of Solanum nigrum, Acokanthera spectabilis and Heliotropium aegyptiacum for each were collected from different places (Abbis, Wady el-Natrun) in Egypt. The collected samples were washed from dust and freshly blended with acetone $(1.0 \mathrm{~L})$ times for a month in the dark at room temperature. Fruits were air-dried for 5 days, ground to fine parts and extracted with $500 \mathrm{ml}$ of methanol at ambient temperature. A gentle warming to $35-40 \mathrm{C}^{\mathrm{o}}$ was sometimes found necessary. The mixture was stirred for 30 minutes by magnetic stirrer and left 24 hr. Then, it was concentrateded in a rotary evaporator under vacuum of solvent in a water bath at $55 \mathrm{C}^{\circ}$ according to Chitra et al., 199). The resulted filtrate was further concentrated to $0.25 \mathrm{~L}$ for each plant fruit.

Test procedure: Stock solutions of three plant methanolic extracts were prepared by dissolving the extracted in warm distilled water (at $0.5 \mathrm{~g} / 100 \mathrm{ml}$ water) containing $0.5 \%$ Triton X100 as an emulsifier to ensure complete solubility of the extract in water. Different concentrations of 100, 200, 300, 400 and 500ppm were prepared from stock solutions. Ten $2^{\text {nd }}$ instar larvae were transferred from the culture into plastic cups $(8 \mathrm{~cm}$ diameter, $10 \mathrm{~cm}$ depth) each containing $30 \mathrm{ml}$ of desired concentration. Treatments were triplicate and control had only distilled water. Larvae were fed daily and kept under laboratory conditions. 500 eggs were treated in water by the same previous concentrations of the plant extracts, 5 replicates (100 eggs for each). Egg hatchability was determined at 2 days after treatment. Larval mortalities were counted at 7 days after treatment. Percentage of successful pupation and adult emergence were determined by monitoring on daily basis until all adults in the control have emerged.

Haemocyte studies: The hemolymph of treated larvae with the $\mathrm{LC}_{50}$ of each tested plant extract were separately smeared to thin film between two glass slides .The blood smears were air-dried, stained with Wright's blood stain (Essawy, 1990) for $1 \mathrm{~min}$ and distained for 2 min. with $70 \%$ ethyl alcohol.
The larval hemocytes were examined using light microscope. Blood samples were obtained from 5 larvae of each extract and control . Each blood sample was replicated three times. The haemocyte types were examined and identified under oil immersion (100X) using a stereomicroscope. Different Haemocyte Count (DHC) was carried out in random scans of blood films (100 haemocytes from each film). The identification of haemocyte types were performed according to (Arnold and Hinks, 1983) . In addition, the surface areas of each haemocyte type were measured by a micrometric slide in all treatments plus the control.

Statistical analysis: Data were analyzed using maximum likelihood procedures and values of $\mathrm{LC}_{50}$ were calculated according to finney (1971). Data were corrected for control mortality (Abbott, 1925). Data of egg hatchability were analyzed by analysis of variance. If significant differences $(p<0.05)$ occurred, means were separated by Duncan's multiple range test.

\section{RESULTS AND DISCUSSION}

The mortality of $C$. pipiens larvae treated with three plant methanolic extracts and their $\mathrm{LC}_{50}$ values and $95 \%$ confidence limits at $48 \mathrm{hr}$ after treatment are shown in Table 1. Results showed that the most toxic extract was $S$. nigrum followed by $A$. spectabilis and $H$. aegyptiacum at the concentration of $500 \mathrm{ppm}$, the larval mortality was $77.5 \%$ after $48 \mathrm{hr}$ of exposure in the case of $S$. nigrum, while it was $64.7 \%$ after $48 \mathrm{hr}$ in the case of A. spectabilis, whereas the larval mortality was $21.7 \%$ after $48 \mathrm{hr}$ in the case of $H$. aegyptiacum. $\mathrm{LC}_{50} \mathrm{~s}$ and $95 \%$ confidence limits (CL) for each plant are given in Table 1. Data showed a significant differences. $\mathrm{LC}_{50}$ for $2^{\text {nd }}$ instar larvae were $130.8,403.5$ and 470.9 for $S$. nigrum, A. spectabilis and $H$. aegyptiacum, respectively, after $48 \mathrm{hr}$ of exposure. S. nigrum was significantly more toxic at all exposure times than A. spectabilis and H. aegyptiacum.

Egg hatchability was not significantly reduced $(p<0.05)$ by treatment with all extracts compared with control (Table 2). Whereas the larval mortality was significantly reduced. S. nigrum extract at $500 \mathrm{ppm}$ revealed the most severe effect on larval mortality which compared with $A$. spectabilis and $H$. aegyptiacum. At concentration of $500 \mathrm{ppm}, S$. nigrum, A. spectabilis and $H$. aegyptiacum caused reduction in larval mortality of $67.5,66.5$ and $63.6 \%$, respectively. The effect of the three plant extracts on growth and development of $C$. pipiens larvae to adulthood are given in Table 2. There were considerable reduction in the percentage of larvae undergoing successful pupation in all treatments compared with control. No further larval development took place after the $2^{\text {nd }}$ instar in S. nigrum at $500 \mathrm{ppm}$. 
Table 1. Mortality percentage of $2^{\text {nd }}$ larvae of Culex pipiens larvae in media containing methanolic plant extracts at different exposure periods

\begin{tabular}{|c|c|c|c|c|}
\hline Plant extract & Conc (ppm) & $\begin{array}{l}\text { Mortality \% after } \\
48 \mathrm{hr} \text { of exposure }\end{array}$ & Slope \pm S.E. & $\mathbf{L C}_{50}(95 \% \mathrm{CL})^{*}$ \\
\hline \multirow{5}{*}{ Solanum nigrum } & 100 & 46.1 & \multirow{5}{*}{$1.2 \pm 0.8$} & \multirow{5}{*}{$130.8(95.8-190.1)$} \\
\hline & 200 & 54.6 & & \\
\hline & 300 & 57.2 & & \\
\hline & 400 & 65.9 & & \\
\hline & 500 & 77.5 & & \\
\hline \multirow{5}{*}{$\begin{array}{c}\text { Acokanthera } \\
\text { spectabilis }\end{array}$} & 100 & 24.9 & \multirow{5}{*}{$1.3 \pm 1.1$} & \multirow{5}{*}{$403.5(360-442)$} \\
\hline & 200 & 30.1 & & \\
\hline & 300 & 35.3 & & \\
\hline & 400 & 52.9 & & \\
\hline & 500 & 64.7 & & \\
\hline \multirow{5}{*}{$\begin{array}{l}\text { Heliotrobium } \\
\text { aegyptiacum }\end{array}$} & 100 & 10.1 & \multirow{5}{*}{$1.5 \pm 2.3$} & \multirow{5}{*}{470.9} \\
\hline & 200 & 12.2 & & \\
\hline & 300 & 14.9 & & \\
\hline & 400 & 16.5 & & \\
\hline & 500 & 21.7 & & \\
\hline Control & 0 & 5.8 & - & - \\
\hline
\end{tabular}

Table 2. Egg hatchability, Larval mortality, Successful pupation and adult emergence of Culex pipiens larvae reared in media containing methanolic plant extracts

\begin{tabular}{|c|c|c|c|c|c|}
\hline Plant extract & $\begin{array}{l}\text { Conc } \\
(\mathbf{p p m})\end{array}$ & $\begin{array}{c}\text { Egg } \\
\text { hatchability at } \\
2 \text { days after } \\
\text { treatment }\end{array}$ & $\begin{array}{c}\text { Larval mortality }(\%) \\
\text { at } 7 \text { days after } \\
\text { treatment }\end{array}$ & $\begin{array}{l}\text { Pupation } \\
(\%)\end{array}$ & $\begin{array}{c}\text { Adult emergence } \\
(\%)\end{array}$ \\
\hline \multirow{5}{*}{ Solanum nigrum } & 100 & $97.8^{\mathrm{a}} \pm 1.8$ & $16.6^{\mathrm{b}} \pm 2.3$ & $18.1^{\mathrm{b}} \pm 1.2$ & $8.5^{\mathrm{b}} \pm 0.9$ \\
\hline & 200 & $97.6^{\mathrm{a}} \pm 2.1$ & $28.2^{\mathrm{c}} \pm 1.9$ & $15.3^{\mathrm{b}} \pm 0.9$ & $6.1^{\mathrm{b}} \pm 1.5$ \\
\hline & 300 & $96.9^{\mathrm{a}} \pm 1.9$ & $46.9^{\mathrm{d}} \pm 0.8$ & $6.8^{\mathrm{c}} \pm 1.5$ & $4.2^{\mathrm{c}} \pm 2.1$ \\
\hline & 400 & $96.7^{\mathrm{a}} \pm 1.6$ & $55.9^{\mathrm{d}} \pm 2.1$ & $5.3^{\mathrm{c}} \pm 2.2$ & $1.8^{\mathrm{d}} \pm 1.4$ \\
\hline & 500 & $97 .^{\mathrm{a}} 2 \pm 3.1$ & $67.5^{\mathrm{e}} \pm 1.8$ & $0.0^{\mathrm{e}}$ & $0.0^{\mathrm{e}}$ \\
\hline \multirow{5}{*}{$\begin{array}{c}\text { Acokanthera } \\
\text { spectabilis }\end{array}$} & 100 & $98.2^{\mathrm{a}} \pm 2.1$ & $13.2^{\mathrm{b}} \pm 1.3$ & $37.9^{\mathrm{b}} \pm 0.8$ & $12.8^{\mathrm{b}} \pm 1.1$ \\
\hline & 200 & $97.9 \pm \pm^{\mathrm{a}} 1.3$ & $25.7^{\mathrm{c}} \pm 1.6$ & $20.1^{\mathrm{c}} \pm 2.8$ & $7.5^{\mathrm{c}} \pm 2.2$ \\
\hline & 300 & $97.6^{\mathrm{a}} \pm 1.6$ & $42.9^{\mathrm{d}} \pm 1.1$ & $13.9^{c} \pm 1.7$ & $4.9^{\mathrm{c}} \pm 2.9$ \\
\hline & 400 & $97.5^{\mathrm{a}} \pm 2.1$ & $54.1^{\mathrm{d}} \pm 1.7$ & $7.2^{\mathrm{d}} \pm 2.1$ & $1.5^{\mathrm{d}} \pm 1.2$ \\
\hline & 500 & $96.9^{\mathrm{a}} \pm 0.9$ & $66.5^{\mathrm{e}} \pm 2.0$ & $0.0^{\mathrm{e}}$ & $0.0^{\mathrm{e}}$ \\
\hline \multirow{5}{*}{$\begin{array}{l}\text { Heliotropium } \\
\text { aegyptiacum }\end{array}$} & 100 & $97.2^{\mathrm{a}} \pm 1.7$ & $11.8^{\mathrm{b}} \pm 0.7$ & $64.9^{\mathrm{b}} \pm 1.1$ & $36.9^{\mathrm{b}} \pm 2.6$ \\
\hline & 200 & $97.5^{\mathrm{a}} \pm 2.8$ & $23.4^{\mathrm{c}} \pm 1.3$ & $55.9^{\mathrm{b}} \pm 2.3$ & $17.9^{c} \pm 3.1$ \\
\hline & 300 & $98.6^{\mathrm{a}} \pm 3.1$ & $39.8^{\mathrm{d}} \pm 3.0$ & $56.9^{\mathrm{b}} \pm 0.9$ & $16.9^{c} \pm 1.1$ \\
\hline & 400 & $96.8^{\mathrm{a}} \pm 2.4$ & $52.6^{\mathrm{d}} \pm 1.1$ & $29.5^{\mathrm{c}} \pm 1.2$ & $8.1^{\mathrm{d}} \pm 0.8$ \\
\hline & 500 & $97^{\mathrm{a}} \pm 1.3$ & $63.6^{\mathrm{e}} \pm 1.9$ & $9.8^{\mathrm{d}} \pm 2.2$ & $3.2^{\mathrm{e}} \pm 2.9$ \\
\hline $98.2^{\mathrm{a}}$ & $100.0^{\mathrm{a}}$ & $4.1^{\mathrm{a}}$ & $98.0^{\mathrm{a}}$ & 0 & Control \\
\hline
\end{tabular}

Means followed by the same letter are not significantly different at $5 \%$ level, Duncan multiple test.

On the other hand all plant extracts had an evident inhibitory effect even at $100 \mathrm{ppm}$, whereas the successful pupation were only $18.1,37,9$ and $64.9 \%$ for $S$. nigrum, $A$. spectabilis and $H$. aegyptiacum, respectively. Complete suppression for adult emergence was evident in case of S. nigrum, A. spectabilis at 500 ppm. S. nigrum, A. spectabilis and $H$. aegyptiacum at 100 ppm caused 8.5, 12.8 and $36.9 \%$ adult emergence, respectively. 
Considerable biological activity related to toxicity and hindrance of growth and development of the larvae of $C$. pipiens has been observed in this study. S. nigrum was found to cause higher rate of mortality compared to other plant extracts. Srinivasan et al. (2013) found that Solanum sarrachoides was effective against green peach aphid. A. spectabilis and $H$. aegyptiacum exhibited a relatively mild acute effect on mosquito larvae especially in its lower concentrations. However, after 8 days of exposure the toxicity was almost high above 200 ppm. The larvicidal activity of some plant extracts, essential oils and phytochemicals against $C$. pipiens have been demonstrated (Traboulsi et al., 2005; Abdelgaleil 2006; Michaelakis et al., 2007; Radwan et al., 2008).

Figure 1 showed the effect of the $\mathrm{LC}_{50}$ of the tested plant extracts on the mean number of haemocytes in the haemolymph of $2^{\text {nd }}$ instar larvae of $C$. pipiens. Four haemocyte types indentified as Prohaemocytes ( $\mathrm{Pr}$ ), Plasmatocytes (Pl), Granulocytes (Gr) and Oenocytoides were monitored. With regarded to $S$. nigrum, $A$. spectabilis and $H$. aegyptiacum treatments, a reduction in the percentage of the prohaemocyte was 74.6, 62 and 56.6 , in respect less than control. The number of $(\mathrm{Gr})$ was markedly decreased especially after treatment with $S$. nigrum and A. spectabilis with reduction percentages of 48.8 and 43.6, respectively. The same trend was observed in the number of plasmatocyte which were reduced by 55 and $34.5 \%$, in respect .An increase was observed in the number of (Oe) about 45.16 and 61.3 $\%$, in respect over the control. Furthermore, treatment with the LC ${ }_{50}$ of tested plant extracts caused a decrease in the haemocyte surface areas.

The obtained results in (Fig., 2) proved that after the treatment with the $\mathrm{LC}_{50}$ of $S$. nigrum, A. spectabilis and $H$. aegyptiacum mithanolic extracts, the haemocyte surface areas were markedly decreased when compared to the control. The results indicated that treatments with $H$. aegyptiacum extract (Fig.3b) caused a decrease in all haemocytes surface area by about 33\% in prohaemocyte, $11 \%$ in granulocyte, $13 \%$ in plasmatocyte and $7 \%$ in oenocytoides less than control. The same trend was observed in A. spectabilis extract treatment (Fig.3c)by about $42 \%$ in prohaemocytes, $21 \%$ in granulocyte, $20 \%$ in plasmatocytes and 19\% in oenocytoides less than control. Also, treatment with $S$. nigrum extract caused a marked decrease in the haemocytes surface areas about $48 \%$ in prohaemocyte, $29 \%$ in granulocyte, $27 \%$ in plasmatocyte and $21 \%$ in oenocytoides (Fig.3d) less than control. (Fig.3a)

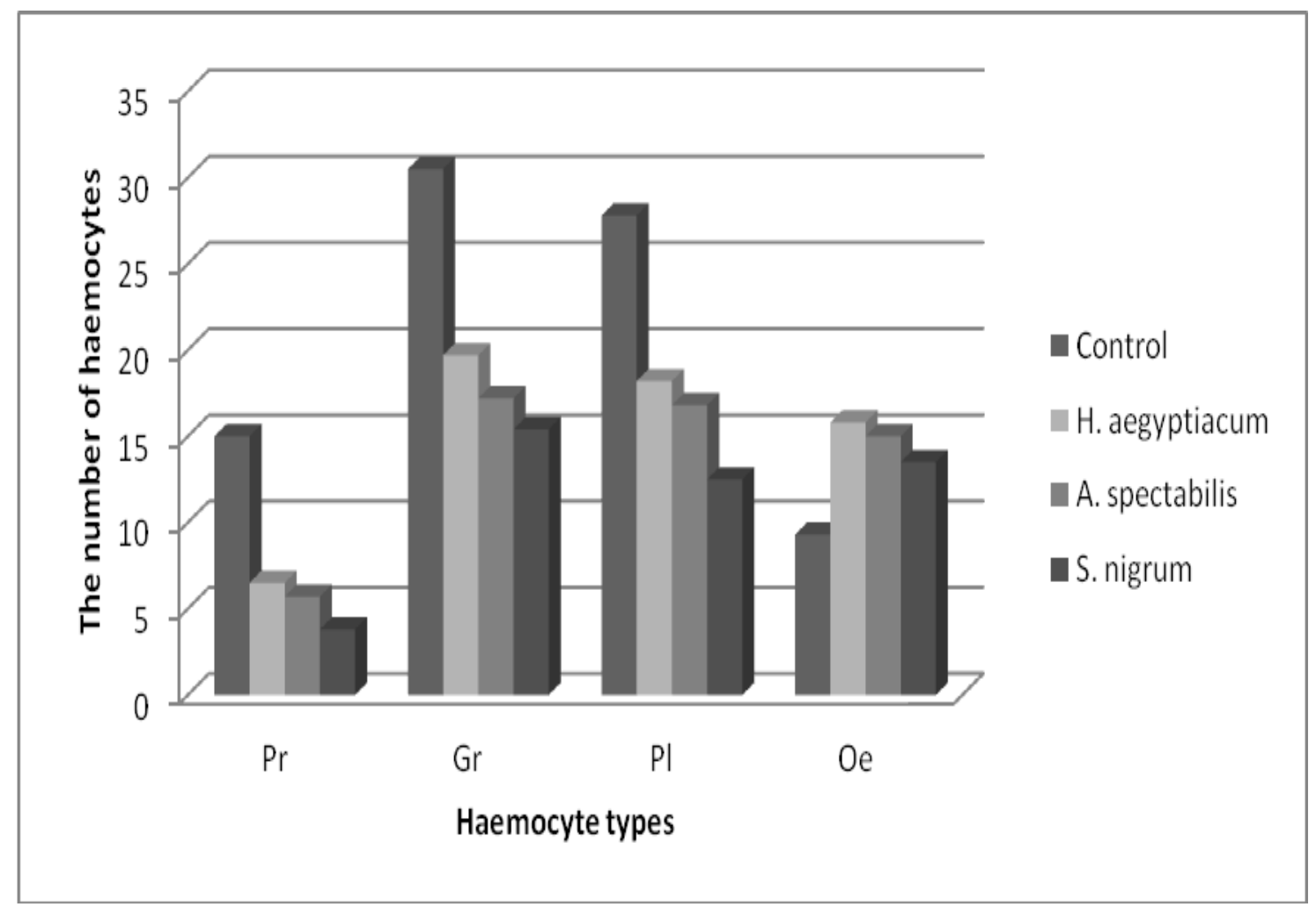

Figure1. Effects of methanolic plant extracts from $S$. nigrum, A. spectabilis and $\boldsymbol{H}$. aegyptiacum on the differential haemocyte count in $C$. pipiens larvae 


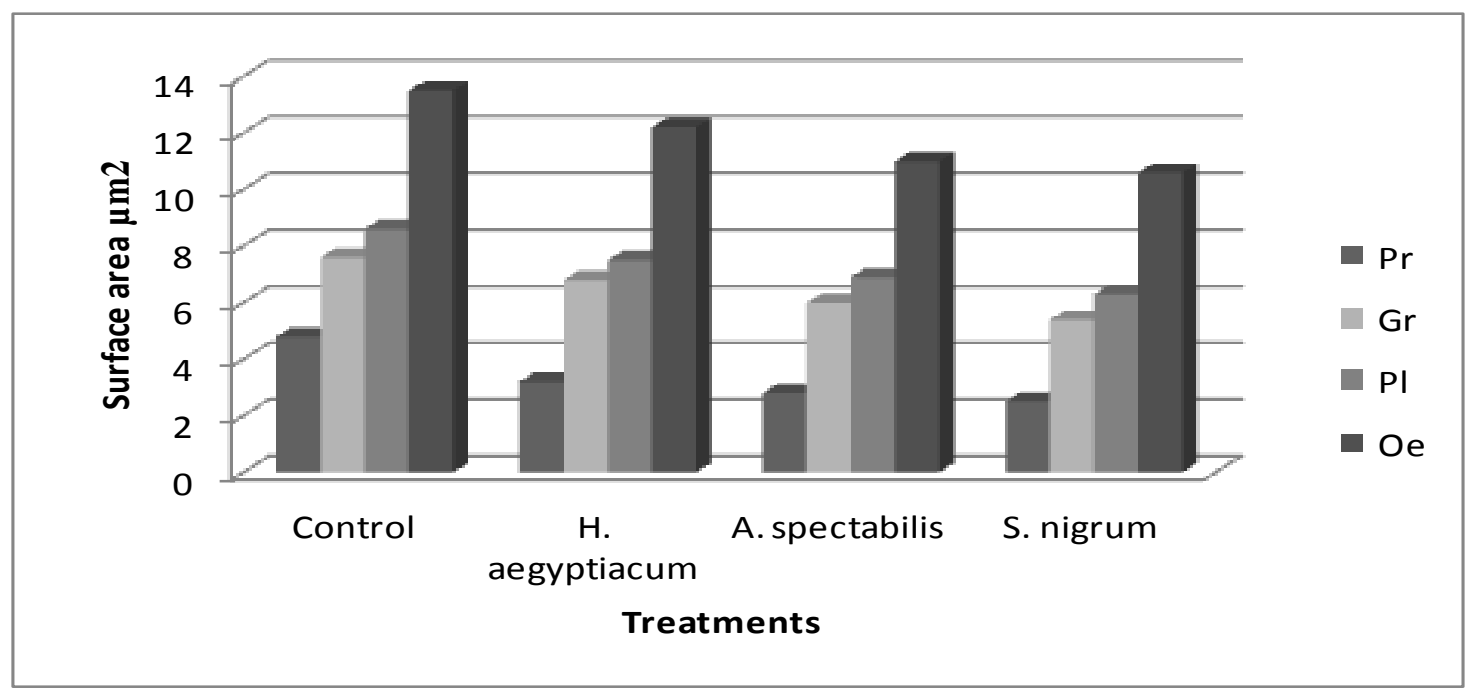

Figure2. Effects of methanolic plant extracts from $S$. nigrum, A. spectabilis and $\boldsymbol{H}$. aegyptiacum on the haemocyte surface area in $C$. pipiens larvae

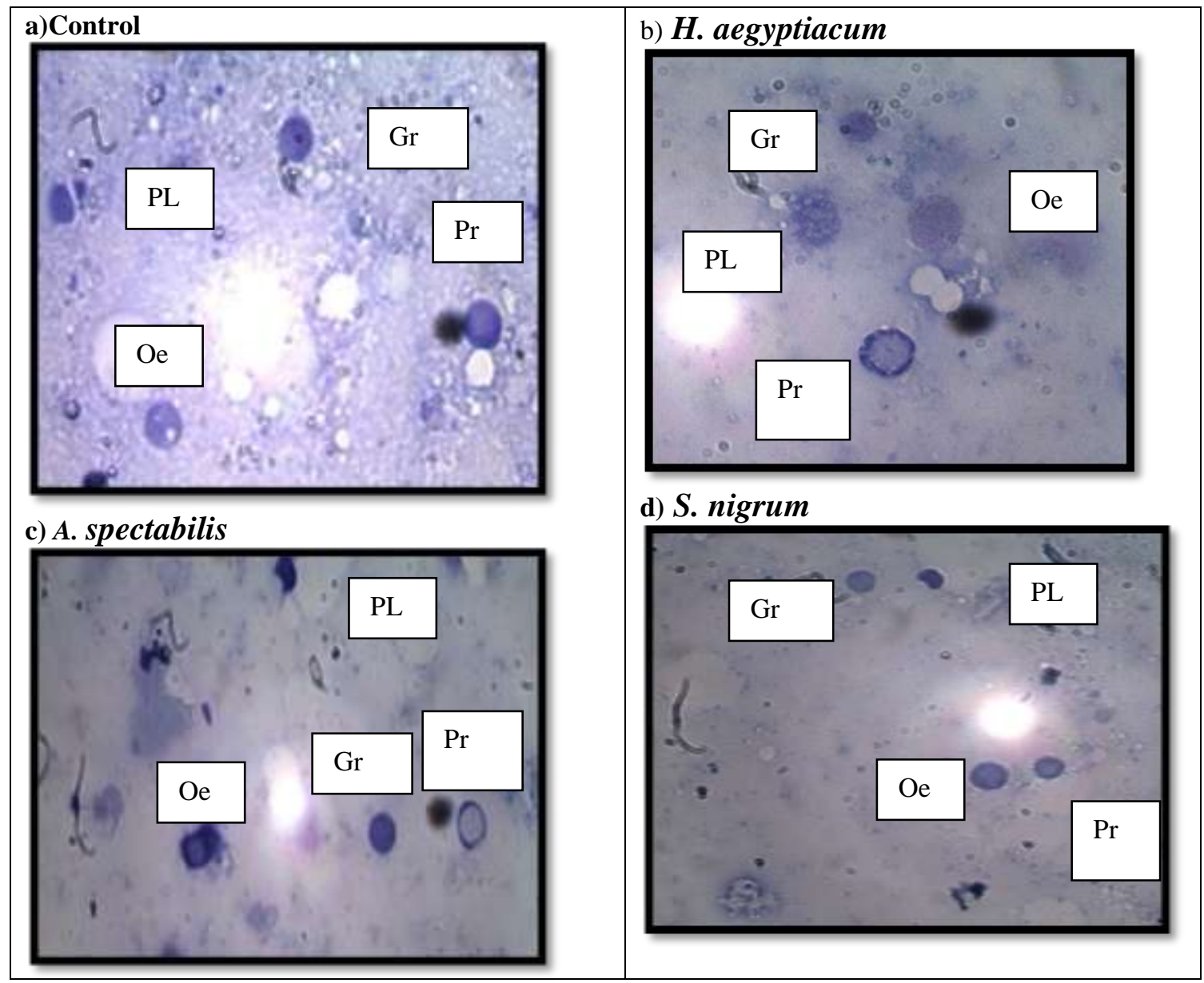

Figure 3.The effect of methanolic plant extracts from $S$. nigrum, A. spectabilis and $H$. aegyptiacum on the $C$. pipiens larval haemogram 
Similar results were reported by Sharma et al. (2008) who noticed that the major effect of Acorus calamus oil treatment was observed on plasmatocytes and granular haemocytes of Spodoptera litura larvae. Gad and El DaKheel (2009) reported that Cinnamomum osmophloeum and Matricharia chamomella oils caused significant decrease in the number of $\mathrm{Pr}, \mathrm{Gr}$ and $\mathrm{Pl}$ and increase the number of Oenocytoide. On contrast, treatment with $C$. osmophloeum and M. chamomella oils caused a significant increase in all haemocyte types surface areas. Saxena and Tikku (1990) proved that plumbagin treatment caused damage in the haemocytes of Dysdercus koenigii and suppression of filopodial elongations of plasmatocytes and granulocytes. Pendey et al. (2007) found that treatment $5^{\text {th }}$ instar larvae of Danais chrysippus caused a marked decrease in the number of haemocytes as well as high variation in relative percentage of different haemocyte types.

The results obtained in this study demonstrate the importance of toxic, growth and development-retarding influence of the extracted plant materials specially $S$. nigrum and A. spectabilis on $C$. pipiens mosquitoes. Moreover, application of these materials is not likely to leave harmful residues in the environment since they are naturally materials occurring among the local flora.

\section{REFERENCES}

Abbott, W.S.(1925) A method of computing the effectiveness of an insecticide. J. Econ. Entomol., 18, 265-267.

Abdelgaleil, S. A.M. (2006). Chemical composition, insecticidal and fungicidal activities of essential oils isolated from Mentha microphylla and Lantana camara growing in Egypt. Alex. Sci. Exchange J.27:18-28.

Al-Doghairi, M.; A. El-Nadi; E. Elhag and H. Al-Ayedh (2004). Effect of Solenostemma argel on oviposition, egg hatchability and viability of Culex pipiens L. larvae. Phytother Res., 18 (4): 335-8.

Arnold, J. W. and Hinks, H. (1983).Haemoposiesis in Lepidoptera. The multiplication of circulation haemocytes. Can.J.Zoo. 154:1003-1012.

Boussaada, O.; M.K. Ben Halima; S. Ammar; D. Haouas; Z. Mighri and A. N. Helal (2008). Insecticidal activity of some Asteraceae plant extracts against Tribolium confusum. Bull. Insectology, 61(2), 283-289.

Carlini, CR. and MF. Grossidi-de-Sa (2002). Plant toxic proteins with insecticidal properties. A review on their potentialities as insecticides. Toxicon. 40, 1515-1539.

Cetin, H.; I. Cinbilgel; A. Yanikoglu and M. Gokceoglu (2006). Larvicidal activity of some Labiatae (Lamiaceae) plant extracts from Turkey. Phytother. Res., 20 (12): 1088-90.
Chitra, K. C.; R. Janarghan; R. Kameswara and K., Nagaiah (1993). Field evaluation of certain plant products in the control of Brinial Pest Complex. Indian Journal of Entomology. 55(3): 237-240.

Dary, O.; G. P. Georghiou; E. Parsons and N. Pasteur (1990). Microplate adaptation of Gomori's assay for quantitative determination of general esterase activity in single insects. J. Econ Entomol., 83 (6): 2187-92.

Das, N.G.; I. Baruah; P.K. Talukadar and S.C. Das (2003). Evaluation of botanicals as repellents against mosquitoes. J. Vect. Borne Dis., 40, 49-53.

Edwards, J. F.; S. Higgs and B. J. Beaty (1998). Mosquito feeding-induced enhancement of Cache Valley Virus (Bunyaviridae) infection in mice. J. Med. Entomol., 35 (3): 261-5.

Essawy, M. M. (1990). Changes in different haemocyte counts of the last larval instar of Spodoptera littoralis (Boised.) during wound healing. Alex. Sci. Exch. 11(4): 151-176.

Finney, D.J. (1971). Probit analysis $3^{\text {rd }}$ edition. Cambridge University press. Cambride, 318pp.

Gad Abir, A , El -DaKheel, Abeer A(2009). Larvicidal activities of Cinnamomum osmophloeum and Matricharia chamomella extracts against the filarial mosquito Culex quinquefasciatus (Diptera:Culicidae)and their effects on its haemogram. Egypyt. Sci. Mag. 6 (1) PP, 8 - 14.

Jang, Y. S.; J. H. Jeon and H. S. Lee (2005). Mosquito larvicidal activity of active constituent derived from Chamaecyparis obtusa leaves against 3 mosquito species. J. Am. Mosq. Control Assoc. , 21(4): 400-3.

Khater, H. F. and A. A. Shalaby (2008). Potential of biologically active plant oils to control mosquito larvae (Culex pipiens, Diptera: Culicidae) from an Egyptian locality. Rev Inst Med Trop Sao Paulo., 50 (2): 107-12.

Kundu, B. R.; R. Ara; M.M. Begum and Z.I. Sarker (2007). Effect of Bishkatali Polygonum hydropiper L. plant extracts against the red flour beetle, Tribolium casteneum Herbst. Univ. J. Zool. Rajshahi Univ. 26, 93-97.

Massoud, A. M and I. M. Labib (2000). Larvicidal activity of Commiphora molmol against Culex pipiens and Aedes caspius larvae. Journal-of-the-Egyptian-Society-ofParasitology., 30 (1): 101-115.

Michaelakis, A.; A. T. Strongilos; E. A. Bouzas; G. Koliopoulos and E. A. Couladouros (2009). Larvicidal activity of naturally occurring naphthoquino-nes and derivatives against the West Nile virus vector Culex pipiens. Parasitol Res., 104 (3): 657-62.

Michaelakis, A.; A. P. Mihou; G. Koliopoulos and E.A. Couladouros (2007). Attract-and-kill strategy. Laboratory studies on hatched larvae of Culex pipiens. Pest Manag. Sci. 63: 954-959.

Pendey, J P , Upandhyay, AK , Tiwarki, RK (2007). Effect of some plant extracts on haemocyte count and moulting of Danais chrysippus larvae. J. Adv. Zool. 28 (1) PP, 14-20. 
Radwan, M. A.; S.R. El-Zemity; S.A. Mohamed and S. M. Sherby (2008). Larvicidal activity of some essential oils, monoterpenoids and their corresponding $N$-methyl carbamate derivatives against Culex pipiens (Diptera: Culicidae) Int. J. Trop. Insect Sci. 28:61-68.

Raymond, M.; C. Berticat; M. Weill; N. Pasteur and C. Chevillon (2001). Insecticide resistance in the mosquito Culex pipiens: what have we learned about adaptation? Genetica., 112-113: 287-96.

Saxena, BP and Tikku, K (1990). Effect of plumbagin on haemocytes of Dysdercus koenigii F. J. Animal Sciences. 99(2), PP. 119-124.

Schmutterrer, H.(1995). The neem tree Azadirachta indica A. Juss and other meliaceous plants, VCH publisher, Weinnein, Germany, 696.

Severini, C.; R. Rom; M. Marinucci and M. Rajmond(1993). Mechanisms of insecticide resistance in field populations of Culex pipiens from Italy. J. Am. Mosq. Control Assoc., 9, 164-186.

Sharma, P.R.; Sharma, O.P. and Saxena, B.P. (2008). Effect of sweet flag rhizome oil (Acorus calamus) on hemogram and ultrastructure of hemocytes of the tobacco armyworm, Spodoptera litura (Lepidoptera: Noctuidae). J. Micron. 39(5), PP. 544-551.
Smartt, C. T. and J. S. Erickson (2008). CNAct-1 gene is differentially expressed in the subtropical mosquito Culex nigripalpus (Diptera: Culicidae), the primary West Nile Virus vector in Florida. J. Med. Entomol., 45 (5): 877-84.

Srinivasan, R.; J. M. Alvarez; F. Cervantes (2013). The effect of an alternate weed host, hairy nightshade, Solanum sarrachoides (Sendtner) on green peach aphid distribution and Potato leafroll virus incidence in potato fields of the Pacific Northwest Crop Protection 46 (2013) 52-56.

Traboulsi, A. F,; S. El-Haj; M. Tueni; K. Taoubi; N. Abi Nader and A. Mrad(2005). Repellency and toxicity of aromatic plant extracts against the mosquito Culex pipiens molestus (Diptera: Culicidae). Pest Manag. Sci. 61: 597604.

Venkatachachalam, MR. and J. Jenbanesan (2001) Larvicidal activity of Hydrocotyle javanica Thumb. (Rutacae) extract against Culex quinquefasciatus. J. Ex. Zool., India, 4 (1), 99-101

Xiaorong, T. and H. Taiping (2008). Separation and identification of botanical insecticide 7-hydroxycoumarin and its biological activity against Aphis craccivora and Culex pipiens pallens. Nat Prod Res., 22 (4): 365-70.

Zhu, J.; X. Zeng; Yanma; T. Liu; K. Qian; Y. Han; S. Xue; B. Tucker; G. Schultz; J. Coats; W. Rowley and A. Zhang (2006). Adult repellency and larvicidal activity of five plant essential oils against mosquitoes. J. Am. Mosq. Control Assoc., 22 (3): 515-22 


\section{الملخص العربي}

\section{تأثير بعض المستخلصات النباتية على موت وتطور وخلايا دم يرقات بعوض الكيولكس بيبينز}

$$
\text { حسام الدين مجدي زهران، عبير عبد المجيد جاد }
$$

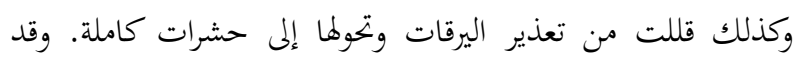
أظهر مستخلص عنب الديب أكبر تأثير حيث كانت نسب التعذير 18.1 عند التركيز 100جزء في المليون. وقد وجد أيضا أن مستخلصات كلا من الأكوكانثيرا ورقيب الشمس المصري كانت فعالة عند وند وند التركيزات الأكثر 100جزء في المليون. وعلاوة علي ذلك وجد أن المستخلصات عنب الديب، الأكوكانثيرا ورقيب الشمس المصري لها

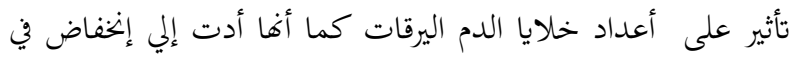
مساحة سطح الخلايا بدرجة ملحوظة. ومن هنا نجد أن المعاملة بهذه المستخلصات في بيئة نمو اليرقات تعطي نتائج أفضل من إستخدام المبيدات الكيميائية التي تسبب ضروا للبيئة والإنسان والحيوان وكذلك قد تبدي الحشرات مقاومة لها.
تم دراسة النشاط الإبادي للمستخلص الميثانولي لكل من عنب الديب، الأكوكانثيرا ورقيب الشمس المصري وذلك ضد ئرقات الثبات وتطور بعوضة الكيوليكس بيبينز. أظهرت المستخلصات النباتية المختلفة

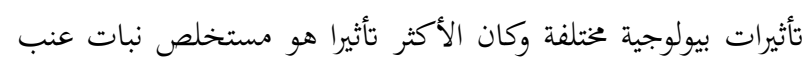

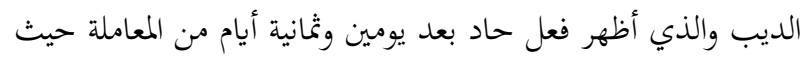

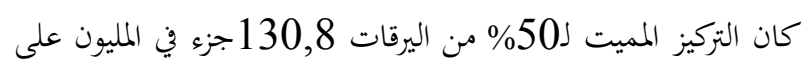

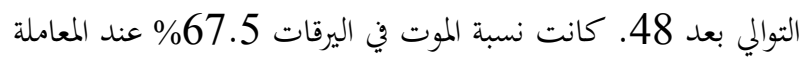

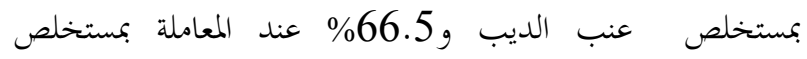
الأكوكانثيرا عند التركيز 500 جزء في المليون. إنخفض فقس البيض بصورة غير واضحة في حالة المعاملة بمستخلص عنب الديب. كل

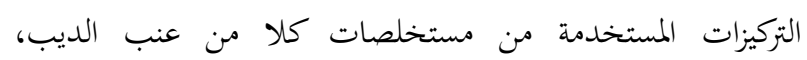

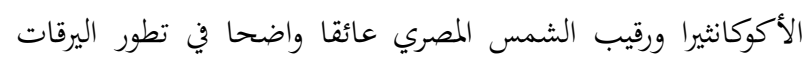

